SBedergi, 2020; 4(6), 122-134

DOI: $10.29228 /$ sbe. 43457

\title{
MÜZİK ÖĞRETIMM YÖNTEMLERİ VE BU YÖNTEMLERİN TÜRK HALK MÜZİĞINDE KULLANILABİLİRLİĞİ ÜZERİNE GENEL BİR DEĞERLENDİRME
}

\author{
Burhan YÜCEDAĞ ${ }^{1}$ \\ https://orcid.org/0000-0003-7396 \\ Sertan DEMİ ${ }^{2}$ \\ https://orcid.org/0000-0002-5062-5266
}

Özet

Müzik eğitiminin; başta çocuklar olmak üzere bireylerin sosyal, duygusal ve piskomotor becerilerini arttırdığı, özgüven ve benlik gelişimine olumlu katkılar sunduğu önemli bir gerçektir. 20. yüzyılda müzik eğitim ve öğretiminin daha sistemli bir hale geldiği, ortaya çıkan yöntemler sayesinde öğretim sürecinin daha da hızlandığı görülmüştür. Çocuğun müzikal belleğini kuvvetlendirmek, kapasitesini arttırmak ve enstrüman öğretiminin ön hazırlığını sağlamak için kullanılan bu sistemler hareket ve perküsyon çalışmalarının da bu sürece katılmasıyla daha etkili sonuçlara ulaşmıştır. Müzikal algının ve becerinin küçük yaşlardan itibaren yapılacak çalışmalarla arttırılabileceği ayrıca kanıtlanmıştır. Bu gelişmeler ışı̆̆ında dünyaca bilinen ve kullanılan C. Orff, Z. Kodally, S. Suziki ve J. Dalcrose gibi müzik bilimcilerin sistemlerinin nasıl oluştuğu, günümüzde nasıl kullanıldığına göz atacağız. Türk halk müziği eğitim ve öğretiminde kullanılabilirliğini inceleyeceğiz. Ülkemizde sistematik olarak bu ve buna benzer metot ve yöntemlerin yeterince anlaşılamamış ve uygulamaya konulamamış olması sorunsalına dikkat çekmek, bu alanda var olan boşluğa değinmek açısından bu çalışma önem arz etmektedir.

Anahtar Kelime; Müzik Eğitim ve Öğretimi, Orff Yöntemi, Dalcroze Yöntemi, Suziki Yönetimi, Kodaly Yöntemi

\section{MUSIC TEACHING METHODS AND A GENERAL EVALUATION OF THE USABILITY OF THESE METHODS IN TURKISH FOLK MUSIC}

\section{Abstract}

It is an important fact that Music education increases social, emotional and psychomotor skills of individuals, especially children, and contribute positively to their self-confidence and self-development. In the 20th century, it

\footnotetext{
${ }^{1}$ Sakarya Üniversitesi, Sosyal Bilimler Enstitüsü, Müzik Bilimleri Yüksek Lisans Programı Öğrencisi, burhan_ycd@hotmail.com

${ }^{2}$ Doç. Dr., Sakarya Üniversitesi Devlet Konservatuvarı Temel Bilimler Bölümü Öğretim Üyesi, sdemir@ sakarya.edu.tr
} 
has been observed that music education and training has become more systematic and the teaching process has been accelerated thanks to the emerging methods. These systems, which are used to strengthen the child's musical memory, to increase his capacity and to provide preliminary preparation for teaching an instrument, have achieved more effective results with the participation of movement and percussion studies. It has also been proven that musical perception and skill can be increased with studies starting from a young age. In light of these developments, we will take a glance at how music scientists such as C. Orff, Z. Kodally, S. Suziki and J. Dalcrose created their well known systems and how they are being used worldwide nowadays.Moreover, we will review the usability of these methods in education and training of Turkish folk music. This study is vital in order to draw attention to the problem that these and other similar methods are not well understood and practiced enough systematically in our country and it is also important to address the gap in this field.

Keywords; Music Education and Training, Orff Method, Dalcroze Method, Suziki Management, Kodaly Method

\section{GíRIŞ}

Müzik, insan yaşamının her evresinde çeşitli yollarla var olan bir olgudur. Günümüzde ise müzik eğitiminin bireylerin kişilik gelişimine önemli katkılar sunduğu gözlenmektedir. Çocukluk döneminde yapılan bu çalışmalardan önemli verimler alındığı görülmekle birlikte çocuğun gelişimine katkı sunduğu, ilerleyen süreçte kişinin kendini öz güvenini arttırdığg, sosyal gelişimini sağlamasında önemli rol oynadığı görülmektedir (Gürgen, 2006: 81). Ali Uçan'ın ifadesiyle: "Müzik, özü itibarlyla eğitsel bir nitelik taşır. Herkes, müzikle ilişkisinin biçimine, yönüne, kapsamına ve derecesine göre ondan bir şey alır; bir şey edinir; bir şey kazanır." (2003: 30).

Müzik eğitiminin temelinde yatan olgu ve kavramlar geçmişten günümüze sürekli bir değişim içindedir. Bu nedenle 20. yüzyılda Orff, Dalcroze, Kodaly, Suzuki gibi önemli eğitimcilerin ortaya koyduğu yeni sitemler günümüz çağdaş dünyasında da geçerliliği olan önemini koruyan öğretim yöntemleridir (Uçan, 2003: 4).

Çağdaş müzik eğitimi anlayışı öğrencinin sürece aktif olarak katıldığı sistemdir. Yaparak ve yaşayarak sürecin içinde olduğu; çocuğun yaratıcılığını ve sosyal becerisini geliştirdiği etkinlikle oyunlardan oluşan süreçtir. Bireyin kalıplarını yıkarak var olan yeteneklerinin keşfini sağlamayı hedefler. Bireyin kendi üretkenliğini arttırarak özgüveni yükselmekte beraber dış dünyaya karşı daha sağlam iletişim kurmasına sebep olmaktadır (Gürgen, 2006: 82).

Eğitimin ön koşullarından olan güdüleme; bilgi aktarımını yapmadan önce ortamın ve öğrenilecek bilgilerin çekiciliğini arttırmak, ilgi çekmeyi sağlamak, öğrenmenin daha iyi ve kalıcı gerçekleşmesine sebep olabileceği gibi eğitim faaliyetini daha kaliteli bir hale getirir. Kişinin öğretim sürecine kendini hazır hissetmesi yapılacak etkinlikte konsantrasyon arttırarak 
daha fazla odaklanma sağlayıp öğrenmenin daha kalıcı olmasını sağlayabilir. Bu durumun başarıyı arttırırken kendine özgüveni pekiştirdiği görülür (Demirel ve Ün, 1987: 78).

Müzik dersinin önemli sorunlarından biride öğrencilerin derse gösterdiği ilgi eksikliğidir. Bunun birçok sebebi olmakla birlikte kullanılmalı ilgi kaynaklı olması da muhtemeldir. Müziği öğrenme içerisinde olabilmek için yetenek ve istek ön koşul gibi görünmektedir. Birçok duyuya hitap eden müzik bedensel olarak ta kavranabilir. Öğrenme sürecinde "müzik ve plastik sanatlar için özel yetenek gereklidir" fikri sanatın birçok alanında olduğu gibi müzik içinde geçerli olup bu öğretim süreçleriyle aşılacak bir olgu olarak kabulde edilebilir ( Ali, 1978: 1).

\section{ARAŞTIRMANIN AMACI, ÖNEMI VE YÖNTEMI}

Günümüzde dünyanın birçok coğrafyasında kullanılan müzik öğretim yöntemlerinin, Türk Halk Müziğinde uygulanması araştırmamızın konusu olacaktır. 20. yüzyılda müzik alanında ortaya atılan birçok eğitim ve öğretim sistemi mevcuttur. Bu eğitim ve öğretim yöntemlerini incelediğimizde; bireylerin erken yaşta yeteneklerinin fark edilip geliştirilmesine sunduğu katkıyı görmekteyiz. Bu sebeple müzik öğretim yöntemlerine genel bir perspektifle bakıp, Türk halk müziğinin öğretimi açısından kullanılmasının mümkün olup olmadığını incelemek adına literatür taraması yaptığımız bu çalışmada, okuyuculara daha geniş bir bakış açısı sağlamayı hedeflemekteyiz. Yapılan bu çalışmada müzik öğretim yöntemleri hakkında genel bilgiler bir arada sunulmuştur. Dünya üzerinde birçok ülkede kullanılan yöntemlerin, ülkemizde müzikal kültürümüzün çocuklara aktarımı üzerindeki etkileri neler olabilir sorusunun cevabını arayacağız. Öğrenme süreçlerinin nasıl gerçekleştiği, neyi hedeflediği ve Türk Halk Müziğinde kullanımı mümkün olunabilir mi sorularının cevabını bulmak açısından önemlidir. Bu araştırma betimsel tarama yöntemiyle yapılıp doküman incelemesi yapılarak kaleme alınmıştır.

\subsection{Araştırmanın Problemi ve Alt Problemleri}

C. Orff, Z. Kodally, S. Suzuki, J. Dalcrose müzik öğretim yöntemlerinin oluşumu, temel esasları ve Türk Halk Müziği öğretiminde kullanılabilirliği nedir?

1- Müzik öğretim yöntemi nedir?

2- Müzik öğretim yöntemleri nasıl oluşmuştur?

3- Müzik öğretim yöntemlerinden Orff, Kodally, Suzuki ve Dalcroze sistemlerinin genel özellikleri nedir?

4- Müzik öğretim yöntemlerinin uygulama safhaları nasıldır? 
5- Yöntemlerin birbirinden farkl1 yönleri nelerdir?

6- Bu öğretim sistemlerinin kabul gördüğü ülkeler nerelerdir?

7- Müzik öğretim sistemlerinin bireyler üzerindeki etkisi nelerdir?

8- Türk Halk Müziği özelinde müzik öğretim yöntemlerinin kullanılması mümkündür?

\section{Müzik Öğretim Yöntemleri}

$\mathrm{Bu}$ başlık altında müzik eğitim ve öğretiminde kendini kanıtlamış sistemli bir öğretiye sahip olan yöntemler açıklanmaya çalışılacaktır. Müzik, ona ilgi duyanların sürekli öğrenmek istediği bir sanat dalıdır. Bu alanda eğitimcilerin yapılan çalışmalarda sürecin daha da hızlanması öğrenmenin daha kalıcı hale gelmesi ve birçok duyuya hitap etmesi düşüncesiyle arayış içerisinde oldukları görülmektedir. Bu arayışlar neticesinde birçok yeni yaklaşım, teknik ve yöntem ortaya atılmıştır. Yapılan çalışmalar kabul görerek ülkelerin müzik eğitimi sürecine dâhil olmuştur. Müzik öğretim yöntemlerinin bireyin kişilik gelişimine olumlu faydalar sağlayabilmesi amacını güttüğü bu sebeple müzikte somut olan birçok kavramın soyutlaştırılmasının müzik öğretim düşüncesinin ana fikri olmuştur (Bilen, 1995: 29).

Müzik eğitiminin temelinde yatan olgu ve kavramlar geçmişten günümüze sürekli bir değişim içindedir. Bu nedenle çeşitli arayışlar içerisine giren Orff, Dalcroze, Kodaly, Suzuki yaptığı çalışmalarla müzik öğretimi daha sistemli bir hale getirmiştir. Ortaya koyulan yeni sitemler günümüz çağdaş dünyasında da geçerliliği olan önemini koruyan öğretim yöntemleridir (Uçan, 2003: 4).

\subsection{Orff Yöntemi Yaklaşımı}

Besteci Carl Orff (1895-1982) ve dansçı Gunild Keetmen'ın çalıştığı yöntem müzik öğretiminde hareket ve söz bileşenlerinin bir araya gelmesiyle müzik eğitiminin yapılması yaklaşımını savunur. (Gürgen, 2006: 3).

Orffe un müziğe bakış açısı, başlangıç itibariyle Avrupa'daki gelişmiş müzik üzerine kurulmuş ve müzikte kaybolmaya yüz tutmuş hareket, doğaçlama ve vurmalı çalgıları bu sistemin ilgi odağına almıştır. Hareket, perküsyon ve doğaçlama; onun müzikteki birinci unsuru olup dansla bağlantılı bir şekilde perküsyon çalgılarının da bu sürece dâhil edilmesiyle müzik öğretiminin kendiliğinden sağlanabileceğini savunur (Orff, 2003: 8).

Orff yöntemi bireyin müzik yaparken bütün becerilerini kullanmasının gerekliliğini vurgular. Çocuğun "bedenselliğin, hareketten müziğe, hareketten dansa, dile, önce görüntü diline, düş gücüne varan sanatsal gücün açığa çıkarılması; insanın teknik ve sanatsal becerisinin sistematik 
yapısıyla, aynı şekilde aklı ve ruhuyla, kafa, yürek ve el birliğiyle" müzik üretme becerisinin daha rahat kazanılacağı fikrini taşır (Jungmair, 2003: 18-26).

Okul öncesi verilecek eğitimde çocuğun eğitim aldığı sınıfta Ezgili Vurma Çalgıları (Orff Çalgıları) olması gerekliliktir. Bu çalgılar okullarda şu nedenle kabul görmüştür:

- Akort problemi yoktur.

- Ses çubukları çocuklar tarafından kolaylıkla değiştirilebilir.

- Taşınması oldukça kolaydır.

- Çocuklarda hem ritim duygusunu hem de ezgi kavramını geliştirir.

- Çocuklarda oyun içinde müzik gelişimini sağlar.

• Çocuklarda küçük kas, büyük kas gelişimini sağlar.

- Devinişsel alanda vücudun diğer organları arasındaki uyumu geliştirir.

• Çocuğun çok sesliliği ve çok ritimli ligi algılamasını sağlar.

- Birlikte iş yapma zevki ve alışkanlığını sağlar.

- Sorumluluk duygusunu geliştirir.

- Çocuk bu çalgıları kullanırken hem sesini, hem de çaldığını işiterek hatalarını kolaylıkla düzeltebilir.

• Çocukları yaratıcılığa yöneltir.

- Farklı tınıları algılaması gelişir.

- Eşlik yapma, eşlikli çalma ve söyleme becerileri gelişir.

- Müziği kendisi yaparak ve yaşayarak öğrenir (Kocabaş, 2003: 62-63).

Carll Orff müziğin en önemli unsurlarından olan ritim ve hareketin çocuğun doğası gereği fazlaca içinde olduğu bu sebeple iki unsurun birbirinden ayrılmaz bir bütün olduğunu savunur. Orff bu sebeple konuşma, söyleme, çalma, söyleme gibi faaliyetleri bir arada kullanır. $\mathrm{Bu}$ sistem çocukları yeteneklerine göre seçmemiş her çocuğun bu öğretim sistemine uygun olduğunu benimsemiştir. Çocuğun kapasitesine göre verilmek istenen eğitim şekillenmeli ve çocuğu esas alan bir eğitim modelidir. Çocukların ilgisinin çekilmesini sağlamak için şarkı söyleme hareket ve oyunlarla bu yöntem desteklenir. Bu süreçte öğretim direk yapılmaz yol gösterilerek farkında olmadan sağlanabilir (Özcan, 2007: 36). 
Orff yönteminde çocuğun bedenini perküsyon gibi kullanması, ritmik hareket etmesi, sesiyle ve ezgilerle yaptığı doğaçlama müzikler haricinde drama ve oyunlaştırılmış müzik etkinlikleri de yer almaktadır. Yapılan bu çalışmalar çocukta yaratıcılığı geliştirmekle birlikte yapılması nedeniyle çocuğun sosyal etkileşimi ve kendine olan öz güvenini de arttırmak açısından önemlidir. (Özcan, 2007: 37).

“Cader (1990: 11 ), Orff yönteminde olması gereken müzikal öğeleri şu şekilde belirtmiştir:

\section{Pentatonik dizi}

2.Ostinato ritim ile eşlik,

3.Çocuklar için uygun müzik materyalleri,

4.Şarkılardan alınmış motifler,

5.Orff çalgıları,

6.Çocuk tekerlemeleri,

7.Ölçünün anlaşılmasını kolaylaştıran konuşma kanonları” (Medford, 2003: 18 ve Tekin,2004: 26).

Orff çocuğun müzikal doğaçlama becerisini yaratma yetisiyle geliştirmek istemektedir. Çocukların dönemsel olarak bu davranışları gösterebilir (Shamrock, 1997: 41 ve Tekin, 2004: 26 ). Yapılan doğaçlamalar çocukta cesaretli olmanın belirtisi halindedir. Öğrencinin kendini ifade edebildiği, yeteneklerinin keşfedildiği bu sistem eğitime uygun ortamın sağlanmasıyla etkisini görebileceğimiz bir yaklaşıma dönüşür. Orff yaklaşımında doğru olandan başka bir doğruya geçilebileceği anlayışı bulunmamaktadır ( Jungmair, 2002, Tekin, 2004: 27).

Orff yaklaşımının "Müzik ve Hareket Eğitimi”, insanların bütün algılarına hitap ederek öğrenme sürecini çok yönlü tutup kuvvetlendirmek ister. Söylenenlerden hareketle Orff yönteminin yaklaşımı bireyin yaratıcılık anlayışını geliştirip sosyalleşmesine ve estetik anlayışının gelişmesine sebep olur. Bu fikre göre müzik yapma anlayışı bireyin kendini gerçekleştirmesinin anahtarı vazifesi görmektedir (Toksoy ve Beşiroğlu, 2006: 23).

\subsection{Dalcroze Yöntemi}

Emile Jaques Dalcroze (1865-1950) besteci ve armoni öğretmeni kimliğiyle öne çıkmaktadır. Geliştirdiği müzik öğretim sistemiyle çocuklarda müzikal işitme algısını geliştirip ritim duygusuyla oyunlar eşliğinde jimnastik hareketlerle öğretim sağlayan sistem beden 
hareketliliğini sistemin merkezine almıştır. Dalcroze yönteminin de iyi bir dinleyici olup fiziksel tepki verme vardır (Dündar, 2003: 2).

Müzik insan hareketlerini temele alan bir sanattır. Kişinin müziğin önemli unsurlarından olan sesi ve kulağı eğitmekle öğrenmenin tam anlamıyla sağlanamayacağını insan vücudunun da bu alanda eğitilmesi gerekir (Şeker, 2005: 24). Dalcroze metodunun kullanıldığı yerlere baktığımızda neredeyse tüm Avrupa, Amerika ve Avustralya'da kullanımının yaygın olduğunu görmekteyiz. Ayrıca Japonya, Çin, Tayvan ve Kore gibi ülkelerde bu öğretim yöntemine ilginin arttığını gözlenmektedir. Kurulan eğitim merkezlerinde sistemlerini yeni öğretmenlere aktarmakta, günümüzde bu eğitimi alıp başarılı olanlara belgeler verilmektedir. Cenevre'deki “Dalcroze Müzik Öğretimi Merkezi” merkez konumdaki eğitim bürosudur. Belge alacak usta öğretmenler yoğun bir eğitim sürecinden geçtikten sonra gerekli tüm bilgi ve beceri sahibi olduktan sonra belgelendirilirler.

\subsection{Suzuki Yöntemi}

Dr. Shinichi Suzuki'nin ortaya attığı bu yöntemin ana öğretim prensibi "anadilin öğrenilmesi” sistemi olarak belirlenmiştir. Çocuk ana dilini nasıl öğreniyorsa süreç içerisinde yeteneğiyle müziği de öyle öğrenmeli fikrini savunur. Çocukların çalgı çalma anlamında profesyonelleşebileceği, dinleme ve taklit yaparak becerisinin ve belleğini daha iyi kullanmasının mümkün olduğunu kanıtlamıştır. Bu yönteme göre yetenek çok çalışarak tekrarla sağlanmalıdır. Çocuk enstrüman eğitimde görerek öğrenir ve bu alanda profesyonel bir hale gelebilir. Müziğe başlama yaşının üç olabileceği düşünülen bu sistemde başlangıç enstrümanı olarak keman önerilir. Keman eğitimi alan çocuğun anadilin öğrenilmesi sürecinde olduğu gibi dinleyerek ve taklit ederek çalışmalara başlaması ezber ve keman üzerindeki hâkimiyetini arttıracaktır fikri mevcuttur. Bu sayede çocuğun müzikal potansiyeli de artmış olur düşüncesi hâkimdir (Özcan, 2007: 46).

Suzuki yöntemi, öğrenmenin erken yaşta gerçekleşmesi, odaklanmada artışın yaşanması, çocuğun bellek gelişiminin artması, müziğe karşı duyarlı olma ve çocuğun kendine güvenini artırmasına karşılık ezberci ve çocuğun yaratıcılığını engelliye bilme fikriyle çokça eleştiri almıştır (Kıvrak, 1994: 4-24 ve Tekin, 2004: 31).

Suzuki yöntemine göre doğuştan bütün insanların potansiyel bir müzik insanı olma yetisi olabileceğini bunu yapılan çalışmalarla daha ileri noktalara taşınabilecekken hayat koşulları sebebiyle potansiyel olması halinde bile bu kapasiteyi kullanamayan bireylerin varlığı söz konusudur. (Bilen, 1995: 31 ). 
Suzuki eğitim sistemine göre çocuk olabildiğince erken yaşta müzik eğitimine başlamalı nota okumanın zorunlu olmadığı bu sistem teknik çalışmalarla etütlerle geliştirilmelidir. Oluşturulan repertuara göre hareket edilmelidir.

$\mathrm{Bu}$ öğretim sisteminin eleştirilmesine sebep olan en önemli etkenlerden birisi de, dinlemenin fazlasıyla öne çıkarılmasıdır. Çocuğun çevresindeki herkesin bu sürece aktif olarak katılması gerekmektedir. Çocuğun konuşmayı öğrenebilmesi müzik aleti çalma becerisinin de kazanabileceği anlamına gelmektedir düşüncesi hâkimdir (Kıvrak, 1994, s. 6-11 ve Ünal, 2006: $15)$.

Dünyanın teknoloji devleri arasında yer alan Japonya'da müzik öğretimi bakış açısına baktığımızda müzik eğitiminin okul öncesi dönemde başlaması gerektiği çocuğun dinleme kültürüne sahip olmasının önemi ve iyi müzik dinleme becerilerinin kazandırılması gerekliği öne çıkar. Müzik dinlemenin yanında kalbine ve duygusuna hitap edebilmelidir. Çocuğun müzikal algısı ve anlayışı bu sebeple gelişir ve hayatının büyük bir bölümüne de etkisi görülebilir (Miyoshi, 1997: 62).

$\mathrm{Bu}$ yöntemi kullanarak eğitim verilen çocuğun nota bilmemesine rağmen bir enstrümanı kulaktan ezbere çalabilme yeteneği oluşturulabilir. Suzuki bu yöntemi çocukların dil öğrenmedeki becerilerinden yola çıkarak uyarlamış başarı elde edebilmiştir. Bu sistemle eğitim veren sistemlere baktığımızda Japonya, İngiltere ve Almanya gibi ülkeleri görmekteyiz. Eğitim öğretici ve özellikle annenin eşgüdümüyle sürdürülmektedir (Çimen, 1995: 23).

\subsection{Kodaly Yöntemi}

Zoltan Kodaly (1882-1967) besteci ve eğitimcidir. Bu yöntem çocuklarda müzik eğitimini iki, üç yaşlarında çocukların rahatlıkla gerçekleştirebileceği şarkı söyleme, dans ve oyunlar yoluyla ritim tutmayla başlar. Kodaly sisteminin en önemli prensibi olarak çocuğun kendi ülkesinin kültüründeki halk şarkılarını öğrenmesi vardır. Nota yazısını da önemseyen bu sistemde algılama ve duyulan sesin yazılmasında el işaretleri gibi nota isimlerinin heceler kullanılır. Kodaly öğretim sisteminde öğretmen tek başına bu süreci yönetmez aile iş birliği önem arz etmektedir (Tufan, 1995: 36).

Sistemin ana prensibi her çocukta var olan müzikal kapasiteyi en üst düzeye çıkartıp müziğin dilini öğretmek bu dille okuyup yazma becerisini kazandırmak kendi kültürünü bu sayede tanımasını sağlamaktır. Çocukları müzikal anlamda yapılan çalışmalarla önemli başyapıtlarla tanıştırıp, bu müzikler üzerinde çalışırken kendilerine güven ve müziğe karşı ilgilerini arttırmak hedeflenmiştir (Yıldırım, 1995, s. 26, Ünal, 2006: 17). 
Kodaly yönteminde dersler teorik kavramlarla başlamaz. Öncelikle çocuğun kulağında olan tanıdığı şarkıların kulaktan öğretimiyle işe başlanır. Bilinenden bilinmeye doğru giden bu sistemde öğretilecek olan müzik farkında olmadan oyunlarla şarkılarla çalıştırılır. Sonrasında semboller devreye girerek tanıtılır işitsel beceri gelişmeden müziksel sembollere yer verilmez (Tekin, 2004: 27).

Kodaly’in çocukların müzikal becerilerini geliştirmek için izlediği yol şöyledir:

1.Daha önce duyduğu şarkıları (halk şarkıları) söylemek, enstrüman çalmak, dans etmek, duyduğu geleneksel kültür ürünü olan şarkı, oyun, tekerleme gibi müziği içerisinde barındıran unsurları öğrenip sonrasında farklı kültürlerin müziklerini tanımak

2.Dünya çapındaki eserleri çalarak performansını arttırmak, bu eserleri inceleyerek analiz etmek.

3.Müzik yazısını bilip okuma, şarkı söylerken koral partileri bilip söyleyebilmek

4.yaşamı boyunca bulunduğu dönemlerde müzikal dağarcığını zenginleştirip bestelerini doğaçlama olarak (Şeker, 2005: 27 ).

Derse başlamada ilk yapılan ritmik yürüyüştür. Bununla çocuklara şarkı söylerken ritmin önemi kavratılmaya çalışılır. Ritmik yürümeyi başarmasıyla "ostinato" adımlara ve alkışlama aşamalarına geçilir. Çocuk şarkıları söylerken ritmine göre yürümesi gerçekleştirilir. Bir sonraki aşama ise bilinen şarkının motiflerini sözleriyle söylenip öğrenciden ritim tutmasını istemektir. Ritim eşliğinde çocuk şarkının sözlerini hecelerken sonrasında öğretmen vurulan ritmi çubuk notasyonu sistemiyle görsele çevirir. Sonrasında bu çalışmalara yeni yaratıcı etkinlikler katılır (Yiğit, 2000: 41ve Tekin, 2004: 28).

Müzik öğretimini dönemlere ayıran Kodaly anaokulu döneminde çocukta müzikal bir dağarcık oluşturur. Çocuk müziğin vermek istediği ana fikri öğrenerek öğretimi devam eder. "Yavaşhızl, uzun- kısa, ritmik ve melodik imitasyon, ostinato, müzikal bellek" müziği dinleme, doğaçlama yapması sağlanarak gelişimi sağlanır. Çocuğun zihinsel olarak müzik üretiminde gösterdiği performans hem zihnini hem de duygusal durumuna katkılar sunar (Yiğit, 2000: 15 ve Ünal, 2006: 18).

"Bilinenden bilinmeyene", "çevreden evrene", "somuttan soyuta" fikriyle oluşturulan Kodaly sistemi şöyledir:

1.Ritm sembolleri ve hecelemeler kullanılır.

2.El işaretleri (solfej ) tonal ilişkilerin görülmesinde kullanılır. 
3.Hareketli "do" kullanılır.

4. Müzikal materyal anadil ve halk müziği ile belirlenir.

5.Konsept çocuk gelişiminin kendi içindeki öğrenim sırası ile paraleldir.

6.Çocuğun sesi en temel enstrümandır.

(http://www.kodaly.org.au/zoltan_kodaly.html, Şeker, 2005: 27-28).

\subsection{Carabo-Cone Öğretim Yöntemi}

Madaleine Carabo-Cone'nin ortaya attığı bu öğretim yöntemi, okul öncesi dönemden başlayıp çocuğa müzik kavramlarını somut bir şekilde öğretilmesi gerektiğini düşünür. İsviçreli psikolog Jean Piaget (1896-1980)'nin çalışmalarından ilham alarak bu yöntemde eğitim sürecinin bir parçası olarak çocuklarında yer alması gerektiği savunulur. Örneğin Do Majör akorunu seslendirmek için bir çocuk do, diğer çocuk mi ve diğeri de sol notasını söyler. Bu yönteme göre çocuklar bir dizi oyunla müziği yaşayarak öğrenmektedirler (Tufan, 1995: 36).

\subsection{Bilinen Diğer Ĕgitim Yöntemleri}

Bu bölüme kadar anlattığımız birçok isim ve sistem müzik eğitiminin daha verimli aktarılması üzerine fikirlerini beyan etmiştir. $\mathrm{Bu}$ yöntemlerin haricinde teorik bilginin nasıl aktarılması gerektiği hakkında birçok eğitimci ve araştırmacı yeni yöntemler üzerinde çalışmıştır. Nota okuma ve solfej eğitiminde notaların somutlaştırılması okunup yazılmasının kolaylaşması açısından yapılan birçok çalışma vardır. (Yönetken, 1952: 82-122 ve Bilen, 199: 32).

Bilinen diğer eğitim yöntemleri Özcan (2007: 48-49) tarafından şu şekilde anlatılmıştır.

"Fransız müzik eğitimcisi olarak bilinen M. Chewais, "Fenomini”" olarak bilinen ses yükseklik ve ritim alıştırmalarını el işaretleriyle sağlanması gerektiğini savunmuştur.. E. Jue “Ed. Jue Yöntemi” adıyla bilinen yöntemde ise yedi notanın ayrı nota başlarılla gösterilmesini öneri olarak sunmuştur. Ptaçinski selerin somut bir hale gelmesi için renklerle ögrretilmesi gerektiğini savunmuştur. Sekiz basamaklı bir merdivende alıştırmalar yapılarak, Do: kırmızı, Re: beyaz, Mi: sarl, Fa: kahverengi, Sol: mavi, La: yeşil, Si: mor. Renkli yöntemde önce kırmızl, mavi, sarı renkler üzerinde, yani do, mi, sol sesleri üzerinde alıştırmalar yapılmakta, sonra sırası ile si, re, fa, la seslerine geçilmektedir. G.L.Wilhem (1781-1842) önerdiği öğretim yönteminde "Wilhem Fransız Yöntemi” ses aralıklarını somutlaştırmak için ses merdivenleri kullanılmış, ritimler sözcüklerle somutlaştırılmıştır”. 


\section{Türk Halk Müziği ve Öğretim Yöntemleri}

Milletlerin kültür ve müziğiyle bir bütün olduğu ve bunu geleceğe aktarma kaygısı güttüğü fikriyle erken yaşta müzik eğitimini hedefleyen bu yöntemleri çocuğun ülkesinin kültür ve müziğiyle özdeşleşmesi için sebep kılabiliriz. Ülkemiz özelinde baktığımızda ise geçmişten günümüze kesintisiz tüm zenginliğiyle gelen Türk Halk Müziği’ni geleceğe aktarımda müzik öğretim yöntemlerinden bizim için uygun olanlarının uygulamaya koyulması fayda sağlayacaktır. Müzik öğretim yöntemlerinin Türk Halk Müziği öğretiminde kullanılması açısından baktığımızda;

Orff ve Dalcroze yöntemlerine baktığımızda daha çok ritim, müziksel işitme, hareket ve doğaçlama üzerine kurulu olduklarını görüyoruz. Vurmalı çalgılarda bu sebeple önemli bir yere sahip bu yöntemlerde. Eğitiminde bu yönde ağırlığının olduğunu görebiliyoruz. Türk Halk Müziğinde kullanım olanağı bu sebepler nedeniyle pek de mümkün görünmemektedir.

Suzuki metodunda öne çıkan anadilin öğrenilmesi prensibidir. Çocuk zamanla duyar taklit ederek yapar kavramsal öğrenmeler daha sonrasın da kazandırılmalıdır. Bu durum halk müziğinin öğretiminde etkili bir yöntem olma ihtimalini arttırırken metodun daha çok enstrüman eğitimi alanında çalışmalara sahip olduğu görülmektedir. Bunun da belirli bir sıra halinde yürümesi gerektiği esastır repertuarın değiştirilmesi söz konusu olmayıp Suzuki metodunda belirtilen eserlerle öğretim devam eder. Bu sebepledir ki halk müziği öğretiminde uyarlanması zor görünmektedir.

Müzik öğretim yöntemlerinin Türk halk müziği üzerinde uygulanabilirliği açısından baktığımızda en uygun olan yöntemin Kodaly yöntemi olduğunu düşünebiliriz. Çocuğun müziği öğrenmesinde kendi kültürünün halk şarkılarının önemli bir etken olduğunu savunur. Müzik eğitimine bunların öğrenilmesi fikriyle başlaması gerektiği hâkimdir. Çocuğun doğumuyla birlikte duymaya başladığı ninnilerden şarkılara o kültürün bir unsurudur ve bu yolla müzik eğitimine başlandığında bu unsurlarla hareket etmek süreci daha hızlı ve verimli bir hale getireceğini düşünülür. Bu sebeple halk müziği eğitiminde Kodaly metodu ülkemiz de kullanılabilir.

Carabo-Cone Yöntemi ve araştırmamızda yer alan diğer öğretim yöntemlerine baktı̆̆ımızda daha çok müzik kavramları üzerinden hareket eden bir anlayışa sahip oldukları görülmektedir. Müziğe kavramsal açıdan yaklaşıp öğretiminde bu şekilde yapılması fikrini savundukları anlaşılmaktadır. Türk halk müziği öğretiminde uygulanması mümkün görünmektedir. 


\section{SONUÇ}

Araştırmamız çerçevesinde bakıldığında dünya üzerinde birçok müzik öğretim yöntem ve sisteminin varlığını görmekteyiz. Bu sistemlerin genel amacının öncelikle bireyin kendini gerçekleştirmesi olduğu anlaşılmalıdır. Kişinin var olan yeteneğini en erken süreçte keşfedip geliştirmek, özgüvenini arttırmak, bireyi daha sosyal kılmak amacında olan bu sistemlerin hedeflerine ulaştığı da görülmektedir. Özellikle Japonya'da piyano, keman çalan ortalama yaşlarının dört, beş olduğu düşünülen çocukların yaşlarına rağmen sergiledikleri performanslar bu sistemlerin yetenekleri keşfedip geliştirme alanındaki faydalarını gözler önüne sermektedir. Yapılan bu çalışmada var olan yöntemler sıralanıp bilgiler verilmiştir. Çalışmamıza konu olan müzik öğretim yöntemlerinin birbirlerinden farklı yönlerinin olduğu görülmektedir. Bunları tespit edecek olursak görmekteyiz ki;

- $\quad$ Orff yöntemine göre ritim, hareket ve doğaçlama birbirinden ayrılmaz bütüncül bir olgu olarak müziğin öğretiminde bir arada kullanılmalıdır ve bütün çocuklarda bu yöntem uygulanabilir fikri hâkimken;

- Dalcroze ise müzikte beden hareketleri ve oyunla müzik öğretiminin gerçekleştirilmesini temel esas olarak kabul eder.

- Suzuki yöntemine baktığımızda ise çocuğun en erken yaşta eğitimine başlaması gerektiğini düşünülür bunu da 3 yaş olarak kabul eder ve anadili öğrenme prensibinden yola çıkarak müziği öğrenmenin de doğal öğrenme tarzında olması gerektiğini savunulur. Taklit ederek görüp öğrenme fikrini taşıyan bu yöntem çokça tekrar ve aile katılımıyla gelişimin sağlanabileceğini savunur.

- Kodaly öğretisine baktığımızda ise dans, şarkı söyleme gibi yollarla öğretim yapmayı hedeflediğini görmekteyiz. Ayrıca önemli bir unsur olarak da öz kültür öğretisi vurgusunun olduğunu söyleyebiliriz.

- Carabo - Cone yöntemi somut öğrenmelerle müzik öğretiminin yapılması gerektiği fikrini önemsediğini görmekteyiz (Dündar, 2003).

Sonuç olarak baktığımızda beş öğretim yönteminin dünya genelinde yaygın olarak kullanıldığı, toplamda ondan fazla yöntemin varlığından söz edebiliriz. Bu yöntemlerin ortak noktasının; erken yaşta uygulamaya başlanıp çeşitli yollarla çocuğun müzikal kapasitesinin arttırılmak istenmesidir diyebiliriz. Türk Halk Müziği’nin çocukluk döneminde sevdirilmesi ve eğitiminin verilmesi öğretim yöntemlerinin kullanılmasıyla mümkün görünmektedir. 


\section{KAYNAKÇA}

Ali , F. (1987). Müzik ve Müziğimizin Sorunları. İstanbul: Cem Yayınevi.

Bilen , S. (1995). İşbirlikli Öğrenmenin Müzik Öğretimi ve Güdüsel Süreçler Üzerindeki Etkileri Yayımlanmamış Doktora Tezi. D.E.Ü. Eğitim Bilimleri Enstitüsü.

Çimen , G. (1995). Piyano Başlangıç Metotlarına Genel Bakış. Mavi Nota Müzik ve Sanat Dergisi.(16).

Demirel, Ö. (2006). Yurtluk, M., Erdem,E., Ekinci,N., Köksal,N., Doğan,N.. Ĕgitimde Yeni. Ankara: Pagem Yayıncılı.

Dündar, M. (2003). Müzik Öğretmeni Yetiştirmede Alanda Eğitim. Gazi Üniversitesi Gazi Ĕ̈itim Fakültesi Dergisi(23), 59-67.

Gürgen, E. (2006). “Müzik Eğitiminde Yaratıcılığı Geliştiren Yöntem Ve Yaklaşımlar”. İnönü Üniversitesi Ĕ̈itim Fakültesi Dergisi(7), 81-93.

İşpiroğlu, N. (1998). Sanattan Güncel Yaşama,. İstanbul : Pan Yayıncılık.

Jungmair, E. U. (2003). “Geçmişe ve Geleceğe Bakış”. İstanbul Orff Schulwerk Eğitim Ve Danışmanlık Dergisi(3), 18-26.

Kıvrak, M. (1994). Suzuki Yöntemi İle Piyano Yöntemi. Yüksek Lisans Tezi. İzmir: Dokuz Eylül Üniversitesi .

Kocabaş, a. (2003). Müzik Öğretiminin Temelleri. İzmir: Egetan Basım Yayın Dağıtım.

Orff, C. (2003). "Hareketten Doğan Müzik". İstanbul Orff Schulwerk Eğitim ve Danışmanlık Merkezi Info Dergisi(3), 2-4.

Şeker, S. S. (tarih yok). 7 - 11 Yaş Grubunda Orff Öğretisi Destekli Keman Ĕ̈itiminde Başlangıç Metodu. Yayımlanmamış Yüksek Lisans Tezi. İzmir: Dokuz Eylül Üniversitesi Eğitim Bilimleri Enstitüsü.

Tekin, E. (2004). Müzik Alan Derslerinin Müzik Öğretmeni Adaylarının Yaratıcı Düşünme Becerileri Üzerine Etkileri. Yayımlanmamış Yüksek Lisans Tezi. İzmir: Dokuz Eylül Üniversitesi Eğitim Bilimleri Enstitüsü.

Tufan, S. (1997). 4-8 Yaş Grubu Öğrencilerinin Müzik ve Piyano Eğitimi. Mavi Nota Müzik ve Sanat Dergisi(16).

Uçan, A. (2003). “Türkiye'de Müzik Eğitiminin Gelişimi, Orff Okul Öğretisinin Tanımı Ve Uygulanımı-Uyarlanımı ve Orff Anlayışıyla Temel Müzik Eğitiminin Genel Durumu. Uluslararası Orff Schulwerk Müzik ve Dans Pedagojisi Sempozyumu.

Ünal, İ. (2006). 6 - 8 Yaş Çocukları İçin Piyano Eğitimi Veren Kurumlarda Öğretmenlerin Başlangıç Aşamasında Piyano Öğretim Yöntemlerinden Biri Olarak Yaratıcı Dramaya İlişkin Görüşleri. Yayınlanmamış Yüksek Lisans Tezi . İzmir: Dokuz Eylül Üniversitesi Eğitim Bilimleri Enstitüsü.

Yönetken, H. (1952). Okulda Müzik Öğretimi Ve Öğretim Metodları. Ankara : Milli Eğitim Basımevi. 